\title{
ANALISIS KUALITATIF KANDUNGAN FORMALIN PADA TAHU YANG DIJUAL DIBEBERAPA PASAR DI KOTA PALU
}

\section{[QUALITATIVE ANALYSIS OF FORMALIN IN TOFU THAT SOLD IN PALU MARKETS]}

\author{
Rismawaty Sikanna* \\ *Jurusan Kimia FMIPA Universitas Tadulako, Palu. \\ Diterima 29 Februari 2016, Disetujui 5 April 2016
}

\begin{abstract}
It had been an investigation on qualitative analysis of formalin in tofu that sold in Palu markets, purpose of this study was to identifity content of formalin in samples of tofu.This identification can know with changes of the colour of the filtrate in samples of tofu from pink to be brown until the colour fed off in 30 minutes. Samples of tofu were taken from some traditional and modern markets in Palu city. The results obtained $66.7 \%$ of all of tofu samples identified content of formalin there were 6 samples with sign of M-3, T-2, T-6, T-5, M-2, and T-4, but 3 samples with sign of T-3, M-1 and T-1 not found. It was supported of texture of tofu samples. There showed that producen of tofu in Palu city is still using formalin as preservative substance in process of tofu production.
\end{abstract}

Keywords: Qualitative analysis of formalin, tofu.

\begin{abstract}
ABSTRAK
Penelitian tentang analisis kualitatif kandungan formalin pada tahu yang dijual di beberapa pasar di kota Palu telah dilakukan, yang bertujuan untuk mengidentifikasi adanya kandungan formalin pada sampel tahu. Identifikasi ini dapat diketahui dengan adanya perubahan warna pada filtrat sampel tahu dari warna merah muda (pink) menjadi coklat dan berangsur-angsur hilang setelah 30 menit. Sampel tahu diambil dari beberapa pasar tradisional $(\mathrm{T})$ maupun modern $(\mathrm{M})$ yang ada di kota Palu. Dari hasil penelitian ini diperoleh bahwa $66,7 \%$ dari keseluruhan sampel tahu teridentifikasi mengandung formalin yaitu 6 sampel dengan kode M-3, T-2, T-6, T-5, M-2, dan T-4, sedangkan 3 sampel dengan kode T-3, M-1 dan T-1 tidak mengandung formalin. Hasil tersebut juga didukung oleh ciri fisik dari sampel tahu berupa teksturnya. Hal ini menunjukkan bahwa Produsen Tahu di kota Palu masih menggunakan formalin sebagai pengawet dalam pengolahan Tahu tersebut.
\end{abstract}

Kata kunci: Analisis kualitatif formalin, Tahu 


\section{LATAR BELAKANG}

Penyalahgunaan bahan-bahan kimia berbahaya sebagai bahan tambahan bagi produk makanan maupun minuman yang tidak sesuai dengan peruntukkannya telah banyak membuat resah masyarakat. Penggunaan bahan kimia seperti pewarna dan pengawet untuk makanan ataupun bahan makanan dilakukan oleh produsen agar produk olahannya menjadi lebih menarik, lebih tahan lama dan juga tentunya lebih ekonomis sehingga diharapkan dapat menghasilkan keuntungan yang sebesar-besarnya. Namun dampak kesehatan yang ditimbulkan dari penggunaan bahanbahan berbahaya tersebut sangatlah buruk bagi masyarakat yang mengkonsumsinya. Keracunan makanan yang bersifat akut serta dampak akumulasi bahan kimia yang bersifat karsinogen merupakan beberapa masalah kesehatan yang akan dihadapi oleh konsumen (Aghnan, 2016).

Dalam proses pengolahan makanan, produsen selalu mengusahakan untuk menghasilkan makanan yang disukai dan berkualitas baik. Oleh karena itu, biasanya produsen sering menambahkan Bahan Tambahan Pangan (BTP) ke dalam makanan. Penggunaan bahan tambahan pangan (BTP) atau food additives sudah sangat meluas. Hampir semua industri pangan, baik industri besar maupun industri rumah tangga, dipastikan menggunakan BTP. Penggunaan BTP memang tidak dilarang asalkan bahan tersebut benar-benar aman bagi kesehatan manusia dan dalam dosis yang tepat. Akan tetapi, terdapat dua permasalahan utama dalam penggunaannya. Pertama, produsen menggunakan BTP yang diizinkan akan tetapi melebihi dosis yang diizinkan. Kedua, produsen menggunakan bahan yang bukan merupakan BTP. Salah satu contoh bahan yang bukan termasuk BTP tetapi sering ditambahkan ke dalam makanan yaitu formalin (Saparianto, 2006). Formalin merupakan larutan yang tidak berwarna, memiliki bau yang menyengat, dan mengandung $37 \%$ formaldehid dalam air (Uddin dkk., 2011). Formalin tidak diperkenankan ada dalam makanan maupun minuman, karena dalam jangka panjang dapat memicu perkembangan sel-sel kanker, iritasi pada saluran pernafasan, reaksi alergi, dan luka bakar. Salah satu makanan yang sering ditambahkan formalin adalah tahu (Nelly, 2011).

Tahu merupakan makanan yang banyak digemari masyarakat, karena rasa dan kandungan gizinya yang tinggi. Tahu dibuat dari kedelai yang merupakan sumber makanan dengan kandungan protein tinggi, dalam $100 \mathrm{gr}$ tahu mengandung $68 \mathrm{gr}$ kalori, protein $7,8 \mathrm{gr}$, lemak 4,6 gr, karbohidrat 1,6 gr, kalsium $124 \mathrm{gr}$, fosfor $63 \mathrm{mg}$, besi $0,8 \mathrm{mg}$, vitamin B 0,06 mg, dan air $84,8 \mathrm{gr}$. Tahu diperoleh melalui proses pengumpalan (pengendapan) protein susu kedelai, bahan yang digunakan adalah batu tahu 
$\left(\mathrm{CaSO}_{4}\right)$, Asam cuka $\left(\mathrm{CH}_{3} \mathrm{COOH}\right)$ dan $\mathrm{MgSO}_{4}$. Secara umum proses pembuatan tahu meliputi, perendaman, penggilingan, pemasakan, penyaringan, pengumpalan, pencetakan/pengerasan dan pemotongan (Sani, 2006). Dalam pengolahan tahu biasanya produsen menggunakan formalin sebagai pengawet agar produksinya dapat bertahan lama dan dapat disimpan jika tidak habis terjual oleh para pedagang tahu di pasaran. Tahu yang berformalin mempunyai ciri-ciri antara lain tekstur kenyal, tidak padat tetapi tidak mudah hancur; awet sampai 3 hari pada suhu kamar, tahan sampai 15 hari dalam lemari es; dan aroma menyengat bau formalin (kadar 0,5-1,0 ppm) (Artikel Kesehatan, 2016).

Kurangnya pengetahuan produsen tahu tentang dampak buruk yang dapat ditimbulkan dari penggunaan formalin untuk jangka waktu yang lama maka masih banyak produsen tahu yang menggunakan formalin dalam proses pengolahan produksinya. Hal ini tentu saja dapat merugikan masyarakat terutama konsumen tahu. Salah satu upaya untuk meminimalisir masuknya formalin ke dalam tubuh sebaiknya masyarakat mulai selektif dalam memilah makanan yang akan dikonsumsi, terutama yang diisukan kerap menggunakan bahan formalin seperti tahu (N.N., 2016). Berdasarkan pengamatan ciri fisik/tekstur seperti kekenyalan pada beberapa produk tahu yang peneliti konsumsi dan dugaan adanya penggunaan formalin sebagai pengawet dalam pengolahan tahu di kota Palu maka penelitian ini dilakukan. Penelitian ini bertujuan untuk mengidentifikasi secara kualitatif adanya formalin dalam tahu yang dijual di beberapa pasar baik tradisional maupun modern di kota Palu.

\section{METODE PENELITIAN}

\section{Bahan dan Peralatan}

Sampel tahu yang berasal dari pasar Tradisional ( $\mathrm{T}$ ) dan pasar Modern (M), larutan $\mathrm{KMnO}_{4} \quad 0,1 \mathrm{~N}$, akuades dan kertas saring.

Alat-alat yang digunakan dalam penelitian ini berupa alat-alat gelas seperti tabung reaksi, gelas ukur, pipet tetes, batang pengaduk. corong penyaring, dan rak tabung.

\section{Prosedur Penelitian}

\section{Analisis kualitatif kandungan formalin} (modifikasi metode Amir, 2011).

Analisis ini menggunakan 2 tabung reaksi yang masing-masing diberi kode $A$ dan B. Tabung reaksi A diisi dengan $2 \mathrm{~mL}$ akuades, lalu ditambahkan 1 tetes larutan $\mathrm{KMnO} 40,1 \quad \mathrm{~N}$ dan diaduk hingga homogen. Tabung reaksi $B$ diisi dengan $10 \mathrm{~mL}$ akuades, lalu ditambahkan $5 \mathrm{gr}$ sampel tahu. Kemudian diaduk hingga homogen, dan disaring untuk diambil filtratnya. Filtrat tahu yang berasal dari tabung reaksi B dimasukkan ke dalam tabung reaksi A. Didiamkan sampai 30 menit. Diamati perubahan warna yang terjadi. Jika warna merah muda pudar, 
menunjukkan sampel tersebut

mengandung formalin.

\section{HASIL DAN PEMBAHASAN}

Sampel yang dianalisis berjumlah 9 sampel yang diambil dari 6 lokasi, masingmasing 3 dari pasar tradisional yaitu pasar
Inpres Manonda, pasar lokal di jl. Srikaya, dan pasar Masomba berjumlah 6 sampel dari produsen yang berbeda, dan 2 dari pasar modern berjumlah 3 sampel. Analisis dilakukan dengan tes kalium permanganat (Amir, 2011).

Tabel. 1. Hasil pengamatan perubahan warna uji formalin

\begin{tabular}{|c|c|c|c|c|c|}
\hline No. & Kode & \multicolumn{3}{|c|}{ Perubahan warna } & Hasil pengamatan \\
\cline { 3 - 5 } & sampel & $\mathbf{0 - 1 0}$ menit & $\mathbf{3 0 \text { menit }}$ & $\mathbf{6 0 \text { menit }}$ & Negatif \\
\hline 1. & T-1 & Merah muda & Merah muda & Merah muda & Positif \\
\hline 2. & T-2 & $\begin{array}{c}\text { Merah muda - } \\
\text { Coklat }\end{array}$ & Bening & Negatif \\
\hline 3. & T-3 & Merah muda & Merah muda & $\begin{array}{c}\text { Merah muda } \\
\text { kecoklatan }\end{array}$ & Positif \\
\hline 4. & T-4 & $\begin{array}{c}\text { Merah muda - } \\
\text { Coklat }\end{array}$ & Bening & & Positif \\
\hline 5. & T-5 & $\begin{array}{c}\text { Merah muda - } \\
\text { Coklat }\end{array}$ & Bening & & Positif \\
\hline 6. & T-6 & $\begin{array}{c}\text { Merah muda - } \\
\text { Coklat }\end{array}$ & Bening & Negatif \\
\hline 7. & M-1 & $\begin{array}{c}\text { Merah muda } \\
\text { 8. Merah muda }\end{array}$ & $\begin{array}{c}\text { Merah muda } \\
\text { kecoklatan }\end{array}$ & Positif \\
\hline 9. & M-2 & $\begin{array}{c}\text { Merah muda - } \\
\text { Coklat }\end{array}$ & Bening & & Positif \\
\hline
\end{tabular}

Dari hasil pengamatan warna (Gambar 1 dan Tabel 1) pada tabung M-3 lebih cepat berubah dari merah muda menjadi coklat dan berangsur-angsur pudar bahkan menjadi bening, dan pada tabung T-1 warna merah muda tidak berubah selama 30 - 60 menit, sedangkan warna pada tabung reaksi T-3 dan M-1 warnanya menjadi merah muda kecoklatan setelah 60 menit. Selanjutnya perubahan tersebut adalah berturut-turut $\mathrm{M}-3>\mathrm{T}-2>\mathrm{T}-6>\mathrm{T}-5>\mathrm{M}-2>\mathrm{T}-4$ (setelah 30 menit), dan $\mathrm{T}-3=\mathrm{M}-1$ (setelah 60 menit), T-1 (tidak berubah). Perubahan warna yang berturut-turut selama 1-30 menit menunjukkan adanya kandungan formalin pada tahu yang diduga mempunyai konsentrasi yang berbeda. Oleh karena itu diperlukan uji lanjut secara kuantitatif untuk mengetahui jumlah kandungan formalin dari masing-masing tahu tersebut, tetapi peneliti tidak melakukan uji lanjut tersebut.

Pada sampel T-3 dan M-1 perubahan warna terjadi setelah 60 menit. Sampel ini diduga tidak mengandung formalin karena menurut Moffat (1986) uji kualitatif formalin positif jika warna yang 
dihasilkan berwarna merah bata dan akan berubah menjadi warna bening dengan waktu yang cepat (kurang lebih 30 menit), tetapi pada kenyataannya perubahan terjadi setelah 60 menit. Oleh karena itu uji formalin terhadap sampel T-3 dan M-1 dinyatakan negatif. Perubahan warna yang terjadi tersebut bukan disebabkan oleh terjadinya reaksi reduksi oksidasi larutan $\mathrm{KMnO}_{4}$ akibat adanya formalin dalam tahu, tetapi terjadi karena sifat $\mathrm{KMnO}_{4}$ itu sendiri yang mudah tereduksi baik dalam suasana asam maupun basa (Khopkar, 1990), sehingga terjadi penurunan bilangan oksidasi yang dapat ditandai dengan dengan adanya perubahan warna larutan $\mathrm{KMnO}_{4}$.
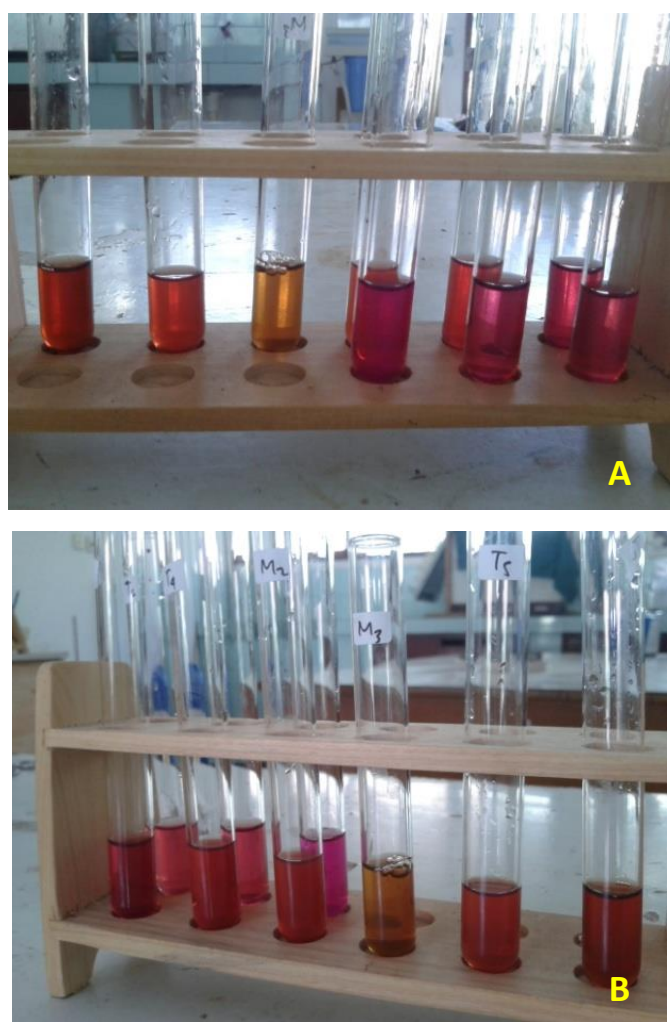

Gambar 1 Perubahan warna selama 0-10 menit (A) dan perubahan warna setelah 10-60 menit (B)
Pada awal reaksi warna yang terbentuk seharusnya adalah warna merah bata yang berasal dari larutan $\mathrm{KMnO}_{4} 1 \mathrm{~N}$. Namun pada penelitian ini konsentrasi larutan $\mathrm{KMnO} 4$ diencerkan menjadi $0,1 \mathrm{~N}$ sehingga warna yang terbentuk lebih muda yaitu merah muda kemudian terjadi perubahan warna menjadi coklat dan akhirnya menjadi bening. Penambahan $\mathrm{KMnO}_{4}$ (kalium permanganat) berfungsi untuk mengoksidasi formaldehid dalam formalin, yang ditandai dengan hilangnya warna merah muda menjadi tidak berwarna (bening). Hilangnya warna merah muda pada sampel mengindikasikan sampel positif mengandung formalin (Moffat, 1986).

\section{KESIMPULAN}

Dari hasil pengamatan dan pembahasan uji formalin setelah 30 menit, dari 9 sampel Tahu yang diujikan diperoleh 6 sampel positif mengandung formalin sedangkan 3 sampel lainnya tidak mengandung formalin. Hal ini menunjukkan bahwa sekitar 66,7 \% dari sampel tahu yang dianalisis dan beredar dibeberapa pasar di kota Palu teridentifikasi mengandung formalin sehingga tidak aman untuk dikonsumsi dalam jangka panjang.

Pada penelitian lanjutan disarankan melakukan uji kuantitaif formalin pada sampel Tahu yang positif mengandung formalin sehingga dapat diketahui 
seberapa besar konsentrasi formalin yang

terkandung di dalam Tahu tersebut.

\section{DAFTAR PUSTAKA}

Amin A. 2011. Identifikasi Formalin dalam Produk Mie Basah dan Tahu dengan Metode Kualitatif Larutan KMnO4. Jurnal Tasimak. 2(1): 1-7.

Aghnan. 2016. Bahan Pengawet dan Penyedap dalam Makanan (BORAKS, FORMALIN, DAN MSG) (https://aghnan354 .wordpress.com/ilmu-pengetahuan /bahan-pengawet-dan-penyedapdalam-makanan-boraks-formalindan-msg). Diakses pada 27 April 2016.

Artikel Kesehatan. 2016. Penggunaan Formalin dalam Produk Pangan. (http://www.smallcrab.com/kesehat an/650-penggunaan-formalin-

dalam-produk-pangan). Diakses pada 30 April 2016.

Khopkar, S.M. 1990. Konsep Dasar Kimia Analitik. Terjemahan: A. Saptorahardjo. UI-press. Jakarta.

Moffat, A. C. 1986. Clarke's Isolation and Identification of Drugs.2 nd Edition. London. The Pharmaceutical Press. Terjemahan: Ngadiwaluyo dan Suharjito, 2003.

Nelly. 2011. Analisis Kualitatif Kandungan Formalin dalam Tahu yang Dijual di Pasar-pasar Tradisional di Kecamatan Medan Area dan Kecamatan Medan Tembung. http://repository.usu.ac.id/handle/1 23456789/31027 (diunduh pada 27 April 2016).

N.N. 2016. Waspadai Penggunaan Formalin pada Bahan Pangan (https://www.deherba.com/hatihati-penggunaan-formalin-dalambahan-pangan.html). Diakses pada 20 April 2016.

Sani E.Y. 2006. Pengolahan Air Limbah Tahu menggunakan Reaktor Anaerob Bersekat dan Aerob. Semarang: Program Magister IImu Lingkungan. Universitas Diponegoro.
Saparinto C. 2006. Bahan tambahan pangan. Yogyakarta: Kanisius.

Uddin R., Wahid M.I., Jesmeen T., Huda N.H., Sutradhar, K.B. 2011. Detection of Formalin in Fish Samples Collected from Dhaka City, Bangladesh. S.J. Pharm. Sci. 4 (1): 49-52. 